\title{
"Magic Rock" Modern Applications: A Review
}

\author{
Himesh Soni*, Sarvesh Sharma
}

D. H. S. Bhopal, India

DOI: $10.36348 /$ sijap.2020.v03i11.001

| Received: 05.11.2020 | Accepted: 16.11.2020 | Published: 19.11.2020

*Corresponding author: Himesh Soni

\section{Abstract}

"Magic Rock" Zeolites are microporous crystalline aluminosilicates resulting from the reaction of volcanic rocks, ash layers and an alkaline groundwater. Zeolites are incorporated the group contain natural silica similarly diatomaceous earth. Zeolites situate apart among the many families of porous materials. They have a number of significant practical properties such as a high adsorption capacity and the ability to cation exchange because of their structure. The present reviews focus on the application of natural zeolites as they were naturally available and abundant, low cost and stable.

Keywords: Zeolite, Clinoptilolite \& $\mathrm{Si} / \mathrm{Al}$ ratio.

Copyright (C) 2020 The Author(s): This is an open-access article distributed under the terms of the Creative Commons Attribution 4.0 International License (CC BY-NC 4.0) which permits unrestricted use, distribution, and reproduction in any medium for non-commercial use provided the original author and source are credited.

\section{INTRODUCTION}

Zeolites are microporous crystalline aluminosilicates derived from the reaction of volcanic rocks, ash layers and an alkaline groundwater. It was first discovery in 1756 by Swedish mineralogist A.F. Cronstedt. Since the most recent millennium, zeolites are acknowledged as a "Magic rock". Zeolite have exclusive characteristic by having large surface area/gram of zeolite because of its porous characteristic. Zeolites have been effectively used as sorbents, ion exchangers, and catalysts for many decades since their discovery in the mid 1700's [1, 2]. Zeolites have microporous structures known as "molecular sieves" named by McBain [3].
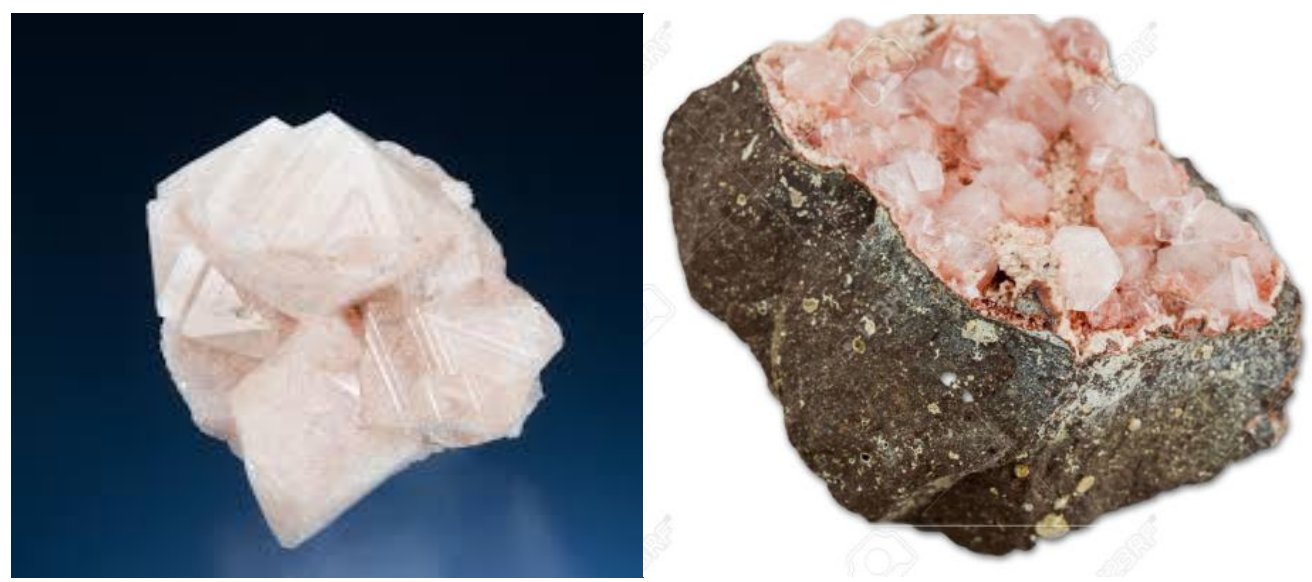

Natural occurring Zeolites

\section{Structure of Zeolite}

Zeolites are composed of pores and corner sharing aluminosilicate $\left(\mathrm{AlO}_{4}\right.$ and $\left.\mathrm{SiO}_{4}\right)$ tetrahedrons, connected into three dimensional frameworks. The pore structure is characterized by cages approximately $12 \AA$ in diameter, which are interlinked through channels about $8 \AA$ in diameter, composed of rings of 12 linked tetrahedrons [4]. 

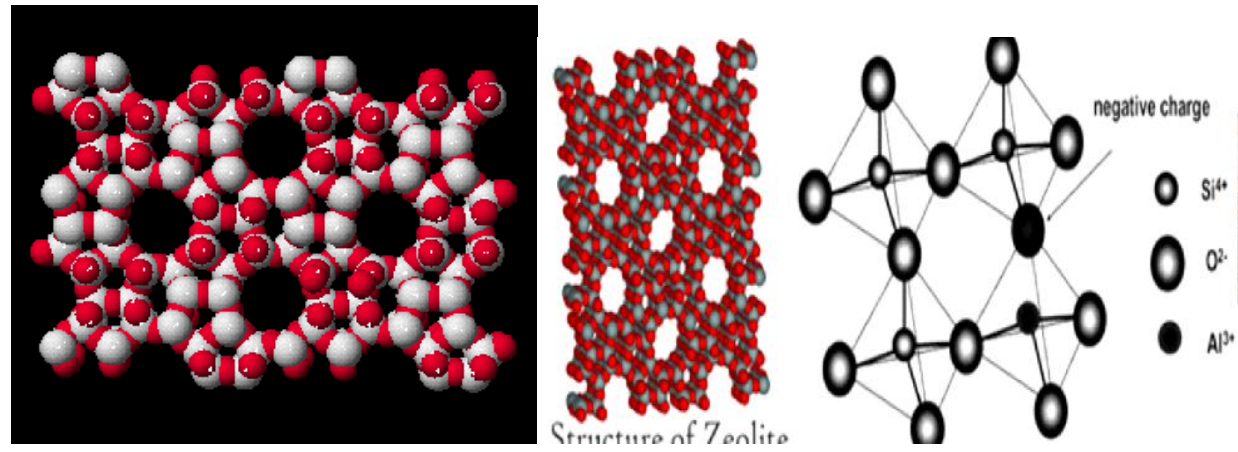

Structure of zeolite

Empirical formula [5]: $\mathrm{M}_{2} \mathrm{nO} \cdot \mathrm{Al}_{2} \mathrm{O} 3 \cdot \mathrm{xSiO}_{2} \cdot \mathrm{yH}_{2} \mathrm{O} \cdot \mathrm{M}$ represents any alkali or alkaline earth cation, $\mathrm{n}$ the valence of the cation, $\mathrm{x}$ varies between 2 and 10, and $\mathrm{y}$ varies between 2 and 7 .

\section{Classification}

More than 50 diverse species of this mineral group have been identified [6]. On the basis of their morphological characteristics, crystal structure, chemical composition, effective pore diameter and natural occurrence zeolites have been classified. Some important species are as follows:

\begin{tabular}{|l|l|l|l|}
\hline Zeolites & Chemical Formula & Porosity $(\%)$ & Bulk density $\left(\mathbf{g} / \mathbf{c m}^{\mathbf{3}}\right)$ \\
\hline Analcine & $\mathrm{NaAlSi}_{2} \mathrm{O}_{6} \cdot\left(\mathrm{H}_{2} \mathrm{O}\right)$ & 18 & 1.85 \\
\hline Clinoptilolite & $\mathrm{Ca}, \mathrm{Na}, \mathrm{K})_{2-3} \mathrm{Al}_{3}\left(\mathrm{Al}, \mathrm{Si}_{2} \mathrm{Si}_{13} \mathrm{O}_{36} \bullet 12\left(\mathrm{H}_{2} \mathrm{O}\right)\right.$ & 34 & 1.15 \\
\hline Chabezite & $(\mathrm{Ca} 0.5, \mathrm{Na}, \mathrm{K})_{4}\left[\mathrm{Al}_{4} \mathrm{Si}_{8} \mathrm{O}_{24} \cdot \bullet_{2} \mathrm{H}_{2} \mathrm{O}\right.$ & 47 & 1.45 \\
\hline Heulandite & $(\mathrm{Ca}, \mathrm{Na})_{2-3} \mathrm{Al}_{3}\left(\mathrm{Al}, \mathrm{Si}_{2} \mathrm{Si}_{13} \mathrm{O}_{36} \cdot 12 \mathrm{H}_{2} \mathrm{O}\right.$ & 39 & 1.69 \\
\hline
\end{tabular}

\section{Occurrences and Distribution}

The annual world production of natural zeolite is about 3 million tones [8].

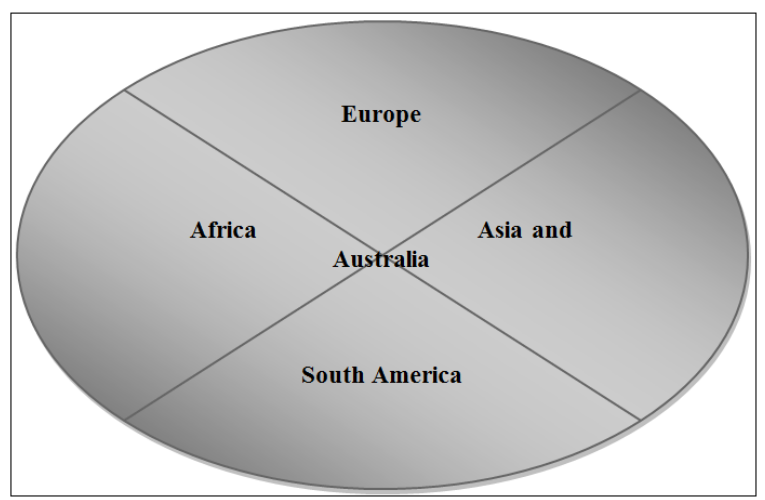

Properties of Zeolites [9-12]

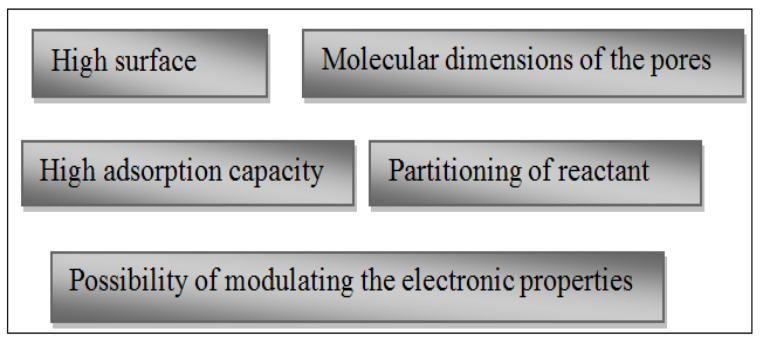

\section{Zeolites Applications [13-16]}

Natural zeolite is a innovative and very good natural filter medium obtainable for the filtration of water. It offers greater performance to sand and carbon filters, giving purer water and higher throughput rates with fewer maintenance required. It has numerous advantages over sand and can be used to directly reinstate sand in a normal sand filter. There are three main uses of zeolite in industry:

\section{Catalysis}

\section{Gas separation}

\section{Ion exchange}

\section{Catalysis}

Zeolites are tremendously functional as catalysts for numerous important reactions involving organic molecules. The most significant are cracking, isomerisation and hydrocarbon synthesis. Zeolites can endorse a varied range of catalytic reactions including acid-base and metal induced reactions. Zeolites also act as acid catalysts and can be used as supports for active metals or reagents. It is also shape-selective catalysts either by transition state selectivity or by exclusion of rival reactants on the basis of molecular diameter. Zeolite also used as oxidation catalysts. The zeolite provides greater control of product because the reaction can take place within the pores space. 


\section{Industrial Application}

- Petroleum refining

- Synfuels production

- Petrochemical production

Synthetic zeolites are the most significant catalysts in petrochemical refineries.

\section{Adsorption}

Zeolites are used to adsorb a diversity of materials. Thus play vital role in drying, purification, and separation. They can eliminate water to very low partial pressures and are very efficient desiccants, with a capacity of up to more than $25 \%$ of their wgt in $\mathrm{H}_{2} \mathrm{O}$. They can eliminate volatile organic chemicals from air streams; divide isomers and mixtures of gases. A extensively used property of zeolites is that of gas separation. They also act as "Sieve" molecules because of porous structure. This property can be fine tuned by variation the structure by changing the size and number of cations approximately the pores. Other process like polymerization of semi conducting material and polymer take place within the pore.

\section{Ion Exchange}

In the aqueous medium, hydrated cations within the zeolite are bounded loosely to the framework, which readily exchange the cations. The use of zeolites in detergents and soaps in water softening devices is seen as the application. The largest volume employ for zeolites is in detergent formulations where they have replaced phosphates as water-softening agents.

\section{Treatment of Industrial Wastewater}

Growing demands for high quality drinking water has lead to a global need to purify water from a variety of sources including natural, industrial, agricultural and municipal waste waters. Therefore, the use of natural zeolites as agents in the removal of wastewater contaminants has gathered incredible interest culminating in widespread studies. Wastewater streams resulting from industrial processes like mining and manufacturing have diverse physical-chemical characteristics. They may contain ions of metals like $\mathrm{Sb}, \mathrm{Cr}, \mathrm{Cu}, \mathrm{Pb}, \mathrm{Zn}, \mathrm{Co}$, and $\mathrm{Ni}$, collectively with waste liquids which are generated by metal finishing or the mineral processing industries. These metals, which are toxic still at trace levels, may survive in these waters at very high concentrations. Such waters should not be discharged directly into natural waters as they pretense an immense risk for the aquatic ecosystem, consequential in numerous types of health problems into animals, plants and human beings.

\section{Treatment of municipal waste waters}

Zeolites mainly reduced the efficiency of the pollutant by a reduction process. Municipal waste water contain ammonium ion $\left(\mathrm{NH}_{4}^{+}\right)$through kitchen, bathroom and laundry in households.

\section{Treatment of Drinking Water}

The discovered of clinoptilolite can improve nitrification of sewage sludge. Natural zeolites have been used in a variety of places for the treatment of municipal wastewater for drinking purposes. By the use of clinoptilolite to sewage before aeration lead to increases in $\mathrm{O}_{2}$ expenditure and sedimentation. This results in a sludge that can be more simply dewatered and, hence, used as a fertilizer [17].

\begin{tabular}{|l|l|}
\multicolumn{2}{l}{ Biological effect of zeolite [18] } \\
\hline Zeolite & Effect \\
\hline Analcime & Antioxidant \\
\hline Phillipsite & Antioxidant and gut microbiota \\
\hline Faujasite & Antimicrobial \\
\hline Erionite & Carcinogenic \\
\hline Clinoptilolite & $\begin{array}{l}\text { Environmental purification, intestinal detoxifier, } \\
\text { antioxidant, anti-inflammatory, antitumor }\end{array}$ \\
\hline
\end{tabular}

\section{Various biological effects of zeolite are as follows} [19]:

- Rising the stability of the immune system and resistance against diseases

- Controlling mineral metabolism

- Body Detoxification

- Blood circulation regulating functions, nervous system, and digestion

- Increasing mental and physical concert

- Inhibition of inflammation, hastening of healing process

- $\quad$ Skin care

- Inhibition of the aging process
- Anti-bacterial and anti-viral potential

- Stress reducing potential

- Soothing \& positive effect on sleep

- Anti-fungal effects

- Decrease of side-effects of pharmaceuticals and other substances

\section{Role of zeolites in Biotechnology and Medicine [20]}

Zeolites are shows potential for environment protection, detoxication of animal and human organisms, enhancement of the nutrition grade and immunity of farm animals, separation of various biomolecules and cells, construction of biosensors and 
biomarkers detection in diverse diseases, controlled drug and gene delivery, radical scavenging, and mainly tissue engineering and biomaterial coating. Zeolites can transport oxygen to cells and act as component of scaffolds for bone tissue engineering. It stimulates osteogenic cell differentiation, and can inhibit bone resorption. They can also act as oxygen reservoirs, and can recover cell performance in vascular and skin tissue engineering and wound healing.

\section{Other Uses [20]}

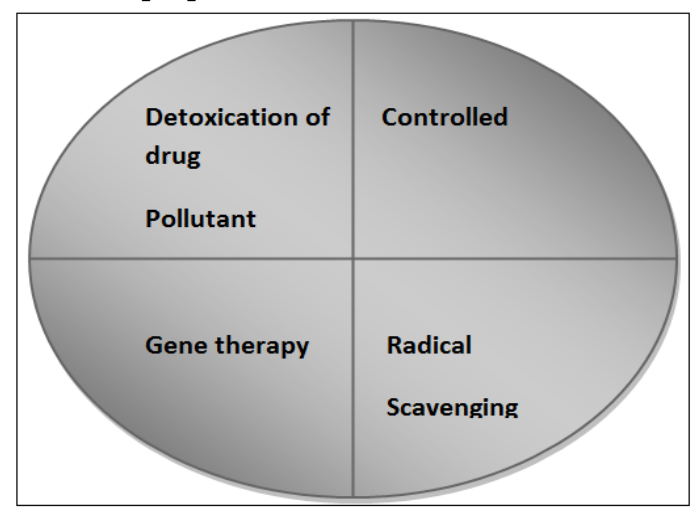

\section{CONCLUSION}

Zeolites symbolize a course group of wellknown minerals and materials with a elevated potential for industrial utilization. Conventional fields are detergent additives, catalysts in cracking processes of the petroleum refining industry and as molecular sieves in environmental applications, soil enhancement and nuclear waste management. Modern inventive applications of zeolites observe their use as host matrices for a large diversity of guests. These hybrid materials can be exploited in numerous research fields, as devices for solar energy harvesting, processing/storing of information, and superior sensing technology for analytics and diagnostics on the nanoscale.

\section{REFERENCE}

1. Barrer, R. M. (1978). Zeolites and Clay Minerals as Sorbents and Molecular Sieves. Academic Press, Inc (London) Ltd.

2. Baerlocher, C. H., McCusker, L. B., \& Olson, D. H. (2007). Atlas of Zeolite Framework Types Amsterdam: Elsevier.

3. McCusker, L. B., Liebau, F., \& Engelhardt, G. (2001). Nomenclature of structural and compositional characteristics of ordered microporous and mesoporousmaterials with inorganic hosts (IUPAC recommendations 2001). Pureand Applied Chemistry, 73, 381-394.

4. Kaduk, J. A., \& Faber, J. (1995). Crystal structure of zeolite $\mathrm{Y}$ as a function of ion exchange. Rigaku $\mathrm{J}$. 12: 1434 .

5. Hemingway, B. S., \& Robie, R. A. (1984). Thermodynamic properties of zeolites: low- temperature heat capacities and thermodynamic functions for phillipsite and clinoptilolite. Estimates of the thermochemical properties of zeolitic water at low temperature. American Minerology, 69: 692700 .

6. Tsitsishvili, G. V., Andronikashvili, T. G., Kirov, G. N., \& Filizova, L. D. (1992). Natural zeolites, Ellis Horwood Ltd, New York, 295.

7. Dogan, H. (2003). Dogal ve Sentetik Zeolitler ve Uygulama Alanlarý, Bor Teknolojileri ve Mineraller Grubu. TÜBITAK Marmara Araptirma Merkezi.

8. USGS Mineral Commodity Sum. (2011). Accessed November 2014.

9. Sun, J., Bonneau, C., Cantín, Á., Corma, A., DíazCabañas, M. J., Moliner, M., ... \& Zou, X. (2009). The ITQ-37 mesoporous chiral zeolite. Nature, 458(7242), 1154-1157.

10. Davis, M. E., Saldarriaga, C., Montes, C., Garces, J., \& Crowdert, C. (1988). A molecular sieve with eighteen-membered rings, Nature, 331(6158), 698699.

11. Csicsery, S. M. (1976). Shape-selective catalysis in zeolites, in Zeolite Chemistry and Catalysis, 171, 680.

12. Csicsery, S. M. (1984). Shape-selective catalysis in zeolites. Zeolites, 4(3), 202-213.

13. Markou, G., Vandamme, D., \& Muylaert, K. (2014). Using natural zeolite for ammonia sorption from wastewater and as nitrogen releaser for the cultivation of Arthrospira platensis. Bioresource Technology, 155: 373-78.

14. Mihajloviae, M., Perisiae, N., Pezo, L., Stojanoviar, M., Milojkoviae, J., Petroviae, M., \& Petroviae, J. (2014). Optimization of process parameters to obtain NH4-Clinoptilolite as a supplement to ecological fertilizer. Clay minerals, 49: 735-745.

15. Moradzadeh, M., Moazed, H., Sayyad, G., \& \& Khaledian, M. (2014). Transport of nitrate and ammonium ions in a sandy loam soil treated with potassium zeolite-Evaluating equilibrium and non equilibrium equations. Acta Ecologica Sinica. 34: 342-350.

16. Mumpton, F. A. (1999). La roca majica: Uses of natural zeolites in agriculture and industry. (In) Proceedings of National Academy of Science, USA. 96: 3463-3470.

17. Moshoeshoe, M., Nadiye-Tabbiruka, M. S., \& Obuseng, V. (2017). A review of the chemistry, structure, properties and applications of zeolites. Am. J. Mater. Sci, 7(5), 196-221.

18. Mastinu, A., Kumar, A., Maccarinelli, G., Bonini, S. A., Premoli, M., Aria, F., ... \& Memo, M. (2019). Zeolite clinoptilolite: Therapeutic virtues of an ancient mineral. Molecules, 24(8), 1517.

19. Karl, H. (2010). Application of natural zeolites in medicine and cosmetology - ZEOMEDCOS. SWB, Baku-London.

20. Bacakova, L., Vandrovcova, M., Kopova, I., \& Jirka, I. (2018). Applications of zeolites in biotechnology and medicine-a review. Biomaterials science, 6(5), 974-989. 